\title{
Methanolic Leaves and Arils Extracts of Ackee (Blighia sapida) Plant Ameliorate Mercuric Chloride-Induced Oxidative Stress in Drosophila melanogaster
}

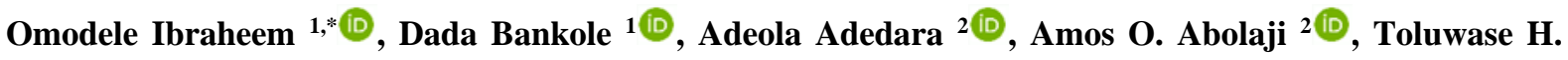 \\ Fatoki $^{1}$ (i), John M. Ajayi ${ }^{3}$ (i), Chukwuebuka T. Eze ${ }^{4}$ (D)
}

1 Plants for Biotechnological Resources Research Group, Department of Biochemistry, Federal University Oye-Ekiti, PMB 373, Oye-Ekiti, Ekiti State, Nigeria; deleibraheem2007@yahoo.com (O.I.); olukole57@gmail.com (D.B.); hezekiahfatoki@gmail.com (T.H.F.);

2 Drug Metabolism and Molecular Toxicology Research Laboratories, Department of Biochemistry, Faculty of Basic Medical Sciences, College of Medicine, University of Ibadan, Oyo State, Nigeria; adedaraadeola@yahoo.com (A.A.); amos_abolaji@yahoo.com (A.O.A.);

3 Bioinformatics and Molecular Biology Unit, Department of Biochemistry, Federal University of Technology Akure, Ondo State, Nigeria; ajayijohn23@gmail.com (J.M.A.);

4 Environmental Toxicology Research Group, Department of Biochemistry, Federal University Oye-Ekiti, PMB 373, OyeEkiti, Ekiti State, Nigeria; thankgod.eze@ fuoye.edu.ng (C.T.E.);

* Correspondence: deleibraheem2007@yahoo.com;

Abstract: Ackee (Blighia sapida) has been used in traditional medicine for treating oxidative stressinduced diseases; diabetes and cancer. Ameliorative roles of Ackee leaves and arils methanolic extracts were evaluated on mercuric chloride $\left(\mathrm{HgCl}_{2}\right)$ induced-oxidative stress in D. melanogaster. 1-3 days old D. melanogaster were orally exposed to different concentrations of Ackee leaves (AL), and Ackee arils (AS) extracts as well as $\mathrm{HgCl}_{2}$ in a diet for 7 days. Subsequently, survival and negative geotaxis assays, quantification of reactive oxygen species (ROS) generation, and oxidative biomarker enzymes were determined. $500 \mu \mathrm{M} \mathrm{HgCl}_{2}$ was selected based on the highest lethality, $0.2 \mathrm{mg} / \mathrm{g}$ for AL, and $0.4 \mathrm{mg} / \mathrm{g}$ for AS; they gave the highest antioxidant effects. Exposure to AL and AS plant extracts improved negative geotaxis behavior and extracts were able to ameliorate the effect of $\mathrm{Hg} 2+$ on catalase positively, acetylcholinesterase, glutathione-S transferase activities, increase total thiol and GSH levels and reverted increased nitric oxide and hydrogen peroxide production $(\mathrm{P}<0.05)$ when compared to the control. Our results suggest that the $\mathrm{Hg}^{2+}$ mechanism of toxicity is associated with oxidative damage, as evidenced by the alteration in the oxidative stress-antioxidant imbalance, and that extracts possess essential phytochemicals that could alleviate possibly effects of environmental pollutants such as $\mathrm{HgCl}_{2}$.

Keywords: Antioxidant; Drosophila melanogaster; environmental pollutants; mercury; oxidative stress damage; reactive oxygen species (ROS); phytochemicals.

(C) 2020 by the authors. This article is an open-access article distributed under the terms and conditions of the Creative Commons Attribution (CC BY) license (https://creativecommons.org/licenses/by/4.0/).

\section{Introduction}

Medicinal plants have found applications in traditional medicine in different parts of the world for thousands of years [1]. The occurrence of natural antioxidants in plants has led to the production of functional food and drugs with health-promoting properties due to their lower toxic effects and higher efficiencies, especially in disease conditions that are often drugresistant [2]. 
Ackee (Blighia sapida) is an inherent tree crop of West Africa, prevalent in tropical and subtropical environments [3] having various parts of it employed in traditional medicine for the treatment of common illness such as fever, malaria, internal hemorrhage, dysentery, yellow fever and diabetes [4] and cancer [5]. About twenty phytochemicals have been reportedly isolated from the various parts of B. sapida [3]. Bioactive molecules such as total phenol, ascorbic acid, hypoglycin A, squalene, D: A-Friedooleanan-7-ol, (7.alpha.) etc. have been identified from the plant [6]. Thus, significant scientific knowledge on the health benefits of these phytochemicals present and their antioxidant potentials could ensure the development of more efficient ways to translate the plant extracts into useful products with improved commercial value.

Drosophila melanogaster, a dipteran insect, is used as a model organism for reproducible research that meets the 3 Rs (reduction, refinement, and replacement) of laboratory animal usage in toxicity studies as recommended by the European Centre for the Validation of Alternative Methods (ECVAM). D. melanogaster finds applications in genetics, biochemistry, and cell biology, and it has been used as a very good model for toxicological study [7]. Drosophila possesses many of the genes systems which control nutrient uptake, storage, and metabolism that are important for the fly development. These genes have shown to be critical for all animal development, including humans, where they have been reported to be analogs to those of humans [8]. Although the final build-up of the fly differs clearly from that of humans, many fundamental building blocks and processes were conserved through evolution and are very comparable based on over $60 \%$ functional gene similarity with humans [8].

.Mercury exists in multiple forms: elemental, organic, and inorganic, and its toxic manifestations depend on the type and magnitude of contact [9]. Most human exposures come from the ingestion of contaminated seafood, outgassing from dental amalgam or occupational exposure (e.g., gold mining), among other cases [10]. It has been reported that mercury has high toxic effects, thus, causing damages to organs and tissues [11]. The study has shown that in $\mathrm{MeHg}^{+}$tolerant strains of Drosophila, cytochrome P450 6g1 (CYP6g1) known as the dichlorodiphenyltrichloroethane resistance allele in flies, and Turandot A (TotA), an immune pathway-regulated humoral response gene, were both highly upregulated and responsive to selection $+\mathrm{MeHg}$ [12]. Hg ions can cause increased cation permeability, decrease intracellular levels of reduced glutathione (GSH), inhibit glucose transport, and accelerate leakage of cytoplasmic lactate dehydrogenase in hepatocytes [13]. Moreover, Hg interferes with a large number of cellular processes, including the formation of complexes with free thiols and protein thiol groups [13], and it could result in oxidative stress [14].

Oxidative stress is thought to be involved in a wide range of diseases such as cardiovascular diseases [CVDs], chronic obstructive pulmonary disease, chronic kidney disease, neurodegenerative diseases, and cancer) [15], and is characterized by an imbalance between reactive oxygen species (ROS) levels (pro-oxidants) and cellular antioxidant defense systems able to counterbalance them, thus resulting in molecular and cellular damage [16]. Oxidative stress has a profound effect on the cellular thiol balance and can lead to a decreased GSH/GSSG ratio in many body organs. Practically, biological macromolecules such as proteins, lipids, and nucleic acids, can have their functional roles altered by oxidative modification due to oxidative stress [17]. Antioxidant enzymes which include catalase (CAT, EC 1.11.1.6), superoxide dismutase (SOD, EC 1.15.1.1), glutathione peroxidase (GPOX, EC 1.11.1.9), glutathione reductase (GR, EC 1.6.4.2), glutathione-S-transferase (GST, EC 2.5.1.18), and its peroxidase activity (GSTPX), are crucial for the removal of toxic forms of 
oxygen and for the termination of the radical oxygen cascade [13]. Induction of these enzymes attenuates the accumulation of toxic oxygen species from an exogenous pro-oxidant. Acetylcholinesterase (AChE) and GST, are an example of biomarkers of electrophilic toxicity [18].

This research was designed to attempt answering the quest for best available remedial strategies for potential biohazards heavy metals such as lead, chromium, arsenic, zinc, cadmium, copper, mercury and nickel, commonly found in contaminated soils have been reported in many rural communities in Nigeria, specifically in Oye-Ekiti community in Ekiti State, Nigeria [19]. The community depends on a good number of wells as sources of domestic water use. The indigenes are mostly peasant farmers and consequently use pesticides and fertilizers, which eventually percolate down the soil and find its way into the groundwater fetch for household uses [20]. The fundamental premise of this research was that it could make the ripe ackee arils that is ubiquitously distributed and primarily consumed in the Oye-Ekiti community be having an ameliorative or alleviating effect; against these deleterious compounds? This study, therefore, investigated the effects of $\mathrm{HgCl}_{2}$-induced oxidative stress in D. melanogaster, and also the ameliorative potential of ackee leaves and arils extracts on behavioral and biochemical disruptions induced by $\mathrm{HgCl}_{2}$ exposure.

\section{Materials and Methods}

\subsection{Chemicals.}

Reduced glutathione (GSH), 1-chloro-2,4-dinitrobenzene (CDNB), acetylcholine iodide, 5'5'-dithiobis-2-nitrobenzoic acid (DTNB), butylated hydroxytoluene (BHT) were purchased from Sigma Chemical Company, St Louis, USA.

\subsection{Sample collection and preparation.}

Mature leaves and arils of Blighia sapida were collected from the Idofin area in OyeEkiti (Latitude $7^{\circ}$ 53' 21.91" N and Longitude $5^{\circ} 20^{\prime} 41.35^{\prime \prime} \mathrm{E}$ ) and transported to Biochemistry Laboratory in Faculty of Science, Federal University Oye-Ekiti, Ekiti State, Nigeria. The plant was authenticated at the Department of Botany, University of Ibadan, with authentication number UCH-22791. They were thoroughly washed, weighed, and blended with absolute methanol. The leaves $(500 \mathrm{~g})$ and arils $(400 \mathrm{~g})$ in $500 \mathrm{ml}$ of absolute methanol were blended to give smooth ground paste and left for 5 hours with continuous stirring and were then passed through a fine sieve cloth. The filtrate was then centrifuged at $1000 \mathrm{rpm}$ for 20 minutes for clarification and to remove any other insoluble particle. The clarified supernatant was then concentrated in a rotary evaporator to $10 \%$ initial volume and afterward evaporated to dryness in a hot air oven at $50^{\circ} \mathrm{C}$. The dried methanolic extract of $B$. sapida leaves and arils were then stored in airtight correctly labeled containers.

\subsection{Collection and treatment of fruit flies.}

Both genders (1-3 day old) of Drosophila melanogaster (Harwich strain) were cultured in the Drosophila Laboratory, Department of Biochemistry, University of Ibadan, Nigeria. The flies were maintained and reared on cornmeal medium containing $1 \% \mathrm{w} / \mathrm{v}$ brewer's yeast, $2 \%$ $\mathrm{w} / \mathrm{v}$ sucrose, $1 \% \mathrm{w} / \mathrm{v}$ powdered milk, $1 \% \mathrm{w} / \mathrm{v}$ agar, and $0.08 \% \mathrm{v} / \mathrm{w}$ nipagin at constant temperature and humidity $\left(23 \pm 1^{\circ} \mathrm{C} ; 60 \%\right.$ relative humidity, respectively) under $12 \mathrm{~h}$ dark/light 
cycle conditions until the eggs metamorphosed into young adult fruit flies. All the experiments were carried out with the same D. melanogaster strain.

\subsection{Phytochemical analysis.}

The qualitative and quantitative screenings and assays of alkaloid, flavonoid, saponin, terpenoid, tannin, and phenolics in the crude methanolic extracts of AL and AS were carried out following previously established experimental methods $[21,22,23,24,25,26]$ as appropriately cited above.

\subsection{Crude plant extracts exposure and survival rate analyzes.}

To determine the appropriate maximum therapeutic doses ackee leaves and arils extracts, 60 days survival and longevity rate were carried out respectively using 1-3 days old flies, in five groups $(n=5)$ of 30 flies each. The plant extracts were introduced into the diet in each group; ackee leaves, AL (0.1, 0.2 and $0.4 \mathrm{mg} / \mathrm{g}$ diet) and ackee arils, AS (0.1, 0.2 and 0.4 $\mathrm{mg} / \mathrm{g}$ diet) respectively. Daily mortality records were taken and plotted as the percentage of live flies, to determine their life span and survival respectively against the control with no extracts. The effects of the extracts on the biochemical parameters in D. melanogaster were determined.

\subsection{Mercuric chloride exposure and survival rate analysis.}

To determine the appropriate toxic dose of mercuric, 14 days survival rate were carried out using 1-3 days old flies, in five groups $(n=5)$ of 30 flies each. Mercury chloride was introduced into the diet of the flies at varying concentrations $(7.5,25,50,100,200$, and 500 $\mu \mathrm{M})$, respectively. Daily mortality records were taken and plotted as the percentage of live flies, to determine their life span and survival respectively against the control with no $\mathrm{HgCl}_{2}$. The effects of the mercury chloride on the biochemical parameters in D. melanogaster were determined.

\subsection{Mercuric chloride exposure and the ameliorative effect of the crude plant extracts.}

Based on the data obtained in sections 2.5 and 2.6, the survival rate of 7 days was selected as the effective doses. Mercuric chloride $(500 \mu \mathrm{M})$ was selected based on highest lethality and $0.2 \mathrm{mg} / \mathrm{g}$ for ackee leaves (AL), and $0.4 \mathrm{mg} / \mathrm{g}$ for ackee arils (AS) were selected as they gave the highest survival and longevity rate compared to the control. To determine the ameliorative effect of ackee leaves and arils extracts in mercuric chloride-induced oxidative stress, 5 days survival assays were carried out using 1-3 days old flies, in five groups $(n=5)$ of 30 flies each and observed till 60 days.

\subsection{Preparation of sample for biochemical assays.}

For the determination of biochemical assays, 50 flies (of both gender) were exposed for 7 days as described above. At the end of the treatment period, the flies were anesthetized with $\mathrm{CO}_{2}$, weighed and then homogenized in $0.1 \mathrm{M}$ phosphate buffer $(\mathrm{pH} 7.4$, the ratio of $1 \mathrm{mg}: 10$ $\mu \mathrm{L}$ ) and centrifuged at $4000 \mathrm{~g}$ for 10 minutes at $4^{\circ} \mathrm{C}$ in a refrigerated centrifuge (Thermo Fisher Sorvall Legend Micro 17R, Fresco). Thereafter, supernatants were transferred into new labeled Eppendorf tubes and used for the determination of total protein, total thiol, glutathione (GSH) 
contents as well as catalase, glutathione S-transferase, and acetylcholinesterase enzyme activities.

\subsection{Protein determination.}

The protein concentrations of the various samples were determined following the Lowry method, as described in Redmile-Gordon et al. [27] using bovine serum albumin (BSA) as a standard.

\subsection{Determination of catalase activity.}

Catalase activity was determined according to the method of Abolaji et al. [17] by monitoring the clearance of $\mathrm{H}_{2} \mathrm{O}_{2}$ at $240 \mathrm{~nm}$ at $25^{\circ} \mathrm{C}$ in a reaction medium containing $1800 \mu \mathrm{L}$ of $50 \mathrm{mM}$ phosphate buffer ( $\mathrm{pH}$ 7.0), $180 \mu \mathrm{L}$ of $300 \mathrm{mM} \mathrm{H}_{2} \mathrm{O}_{2}$, and $20 \mu \mathrm{L}$ of the sample (1:50 dilution). The reaction was monitored for $2 \mathrm{~min}$ (10 secs intervals), at $240 \mathrm{~nm}$ using a Jenway $6305 \mathrm{UV} /$ visible Spectrophotometer (Bibby Scientific Ltd., UK) (expressed as $\mu$ mol of $\mathrm{H}_{2} \mathrm{O}_{2}$ consumed/min/mg protein).

\subsection{Determination of acetylcholinesterase activity and the levels of total thiols.}

Acetylcholinesterase activity and the levels of total thiols were assayed using the methods described by Ellman et al. [28]. The system consisted of $135 \mathrm{~mL}$ of distilled water, $20 \mathrm{~mL}$ of $100 \mathrm{mM}$ potassium phosphate buffer (pH 7.4), $20 \mathrm{~mL}$ of $10 \mathrm{mM} \mathrm{DTNB}, 5 \mathrm{~mL}$ of sample, and $20 \mathrm{~mL}$ of $8 \mathrm{mM}$ acetylthiocholine as initiator. The reaction was monitored for 5 min (15 secs intervals) at $412 \mathrm{~nm}$ using a Spectra Max plate reader (Molecular Devices, USA). The data were calculated against blank and sample blank, and the results were corrected with the protein content.

\subsection{Total thiols Determination.}

The levels of total thiols were assayed using the method of Abolaji et al. [17]. The reaction mixture was made up of $170 \mathrm{~mL}$ of $0.1 \mathrm{M}$ potassium phosphate buffer ( $\mathrm{pH} 7.4), 20$ $\mathrm{mL}$ of sample, and $10 \mathrm{~mL}$ of $10 \mathrm{mM}$ DTNB. This was followed by $30 \mathrm{~min}$ incubation at room temperature, and the absorbance was measured at $412 \mathrm{~nm}$. A standard curve was plotted for each measurement using GSH as standard (expressed as mmol/mg protein).

\subsection{Hydrogen peroxide generation.}

Hydrogen peroxide generation was determined by Wolff's FOX2 assay, as described by Wolff [29]. Briefly, $50 \mu \mathrm{L}$ of the test sample was added to $950 \mu \mathrm{L}$ FOX2 reagent $(100 \mu \mathrm{M}$ xylenol orange, $250 \mu \mathrm{M}$ ferrous ammonium sulfate, 90\% HPLC grade methanol, $4 \mathrm{mM}$ BHT, $25 \mathrm{mM} \mathrm{H}_{2} \mathrm{SO}_{4}$ ), vortexed and incubated for $40 \mathrm{~min}$ at room temperature. The absorbance was read at $580 \mathrm{~nm}$.

\subsection{Reduced glutathione assay.}

Reduced glutathione (GSH) was determined according to the method of Jollow et al. [30]. Briefly, an aliquot was deproteinized by the addition of an equal volume of $4 \%$ sulfosalicylic acid, and after centrifugation, $0.5 \mathrm{ml}$ of the supernatant was added to $4.5 \mathrm{ml}$ of 
bis (3-carboxy-4-nitrophenyl) disulfide (Ellman's reagent). Reduced glutathione was proportional to the absorbance at $412 \mathrm{~nm}$.

\subsection{Determination of nitric oxide level.}

Nitric oxide was evaluated by the measurement of nitrite $\left(\mathrm{NO}_{2}{ }^{-}\right)$levels. The amounts of nitrite in supernatants were measured according to Griess reaction [31] in the presence of a Griess reagent ( $1 \%$ sulfanilamide, $0.1 \% \mathrm{~N}$ - (1-naphthyl) ethylenediamine dihydrochloride, and $5 \% \mathrm{H}_{3} \mathrm{PO}_{4}$ ). After incubation at room temperature, the optical density (OD) was read at 550 $\mathrm{nm}$. Nitrite concentration was calculated from a standard curve generated with sodium nitrite concentrations (0 to $100 \mu \mathrm{M})$.

\subsection{Estimation of Glutathione-S-Transferase activity.}

The glutathione-S-Transferase activity was determined according to the method described by Abolaji et al. [17], using 1-chloro- 2,4-dinitrobenzene (CDNB) as substrate. The assay reaction mixture was made up of $270 \mathrm{~mL}$ of a solution containing (20 mL of $0.25 \mathrm{M}$ potassium phosphate buffer, $\mathrm{pH} 7.0$, with $2.5 \mathrm{mM}$ EDTA, $10.5 \mathrm{~mL}$ of distilled water, and 500 $\mathrm{mL}$ of $0.1 \mathrm{M} \mathrm{GSH}$ at $25^{\circ} \mathrm{C}$ ), $20 \mathrm{~mL}$ of sample (1:5 dilution), and $10 \mathrm{~mL}$ of $25 \mathrm{mM} \mathrm{CDNB}$. The reaction was monitored for 5 min (10 secs intervals) at $340 \mathrm{~nm}$ in a SpectraMax plate reader (Molecular Devices), and the data were expressed as millimole per minute per milligram protein using the molar extinction coefficient $(\varepsilon)$ of $9.6 \mathrm{mM}^{-1} \mathrm{~cm}^{-1}$ for $\mathrm{CDNB}$ conjugate.

\subsection{Investigation of negative geotaxis.}

Locomotor performance of the flies (treated and control) was investigated using the negative geotaxis assay as described by Abolaji et al. [17] About twenty (20) flies each in three groups [B. sapida extracts (AL and AS) treated, $\mathrm{HgCl}_{2}$ treated, and control] were immobilized under $\mathrm{CO}_{2}$ anesthesia placed separately in labeled vertical glass columns (length $15 \mathrm{~cm}$; diameter $1.5 \mathrm{~cm}$ ). After the recovery from $\mathrm{CO}_{2}$ exposure (about $20 \mathrm{~min}$ ), the flies were gently tapped to the bottom of the column. The number of flies that climbed up to the $6 \mathrm{~cm}$ mark of the column in $6 \mathrm{~s}$ as well as those that remained below this mark after this time was recorded. The scores represent the mean of the number of flies at the top ( $\left.\mathrm{n}_{\text {top }}\right)$ expressed as a percentage of the total number of flies ( $\left.\mathrm{n}_{\text {tot }}\right)$. This procedure was repeated three times at a 1-min interval.

\subsection{Statistical analysis.}

The results are expressed as mean \pm SEM (standard error of the mean). Statistical analysis was performed using a one-way analysis of variance (ANOVA) followed by Tukey's post hoc test. The results were considered statistically significant for $\mathrm{P}<0.05$.

\section{Results and Discussion}

\subsection{Phytochemical screening of Blighia sapida leaves and arils.}

Table 1 shows the phytochemical content in leaf and aril extracts of B. sapida. The result showed the degree of presence of these secondary metabolites in the extracts. Saponins, tannins, terpenoids, alkaloids, phenol, and flavonoids were specifically present in the ackee leaves extracts and arils extracts. Moreover, the percent $(\mathrm{w} / \mathrm{w})$ of the phytochemicals as 
contained in the extract are more abundant in the leaves extract compared to the arils extract except for saponins and terpenoids that are slightly higher in the arils.

Table 1. Determination of phytochemical contents of $B$. sapida leaves and aril extracts.

\begin{tabular}{|c|c|c|c|c|c|c|}
\hline Sample & $\begin{array}{c}\text { \% Flavonoid } \\
\text { content } \\
(w / w)\end{array}$ & $\begin{array}{c}\% \text { Alkaloids } \\
\text { content }(w / w)\end{array}$ & $\begin{array}{c}\% \text { Saponin } \\
\text { content }(w / w)\end{array}$ & $\begin{array}{c}\% \\
\text { Terpenoid } \\
\text { content } \\
\text { (w/w) }\end{array}$ & $\begin{array}{c}\text { \% Tannin } \\
\text { content } \\
(w / w)\end{array}$ & $\begin{array}{c}\text { \% Phenol } \\
\text { content } \\
(w / w)\end{array}$ \\
\hline $\begin{array}{c}\mathrm{AL} \\
\text { extract }\end{array}$ & 0.32 & 0.29 & 0.25 & 0.12 & 0.22 & 0.52 \\
\hline $\begin{array}{c}\text { AS } \\
\text { extract }\end{array}$ & 0.25 & 0.18 & 0.21 & 0.15 & 0.10 & 0.37 \\
\hline
\end{tabular}

3.2. Effects of ackee leaves $(A L)$ and arils $(A S)$ and mercuric chloride on longevity and survival of D. melanogaster.

Effects of the methanolic extracts of ackee leaves (AL) and ackee arils (AS) on the longevity of D. melanogaster, throughout their life span, is shown in Figure 1a. The result shows that ackee leaves (AL) at a concentration of $0.2 \mathrm{mg} / \mathrm{g}$ diet extended lifespan the most among the three concentrations tested $(0.1,0.2$ and $0.4 \mathrm{mg} / \mathrm{g}$ diet $)$ by $1.7 \%$, while and ackee arils (AS) at the concentration $(0.4 \mathrm{mg} / \mathrm{g}$ diet $)$ extended lifespan the most among the three concentrations tested $(0.1,0.2$ and $0.4 \mathrm{mg} / \mathrm{g}$ diet $)$ by $3.4 \%$ when compared with control. The effect of mercuric chloride on the survival of D. melanogaster is depicted in Figure $1 \mathrm{~b} . \mathrm{HgCl}_{2}$ decreased survival significantly when compared with the control with $500 \mu \mathrm{M} \mathrm{HgCl}_{2}$ showing the highest lethality.

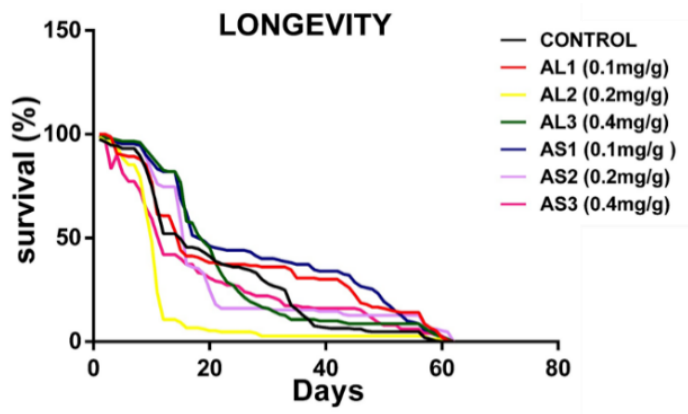

Figure 1a. Effects of $B$. sapida on the lifespan of Drosophila melanogaster. The $0.1,0.2$, and $0.4 \mathrm{mg} / \mathrm{g}$ diet of Ackee leaves (AL) and Ackee arils (AS) extended the survival of the flies beyond the 60 days lifespan of $D$. melanogaster observed in the control experiment. However, $0.2 \mathrm{mg} / \mathrm{g}$ for ackee leaves (AL) and $0.4 \mathrm{mg} / \mathrm{g}$ for ackee arils (AS) were selected as they gave the highest survival and longevity rate compared to the control at 7 days.

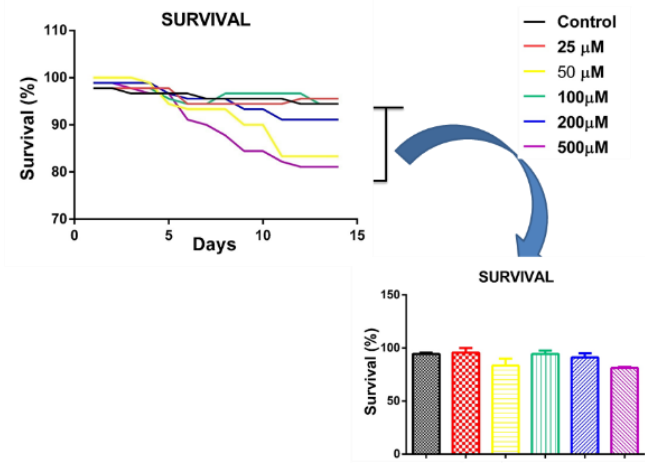

Figure 1b. Effects of mercuric chloride on the survival of Drosophila Melanogaster. (A) Survival curve analysis and (B) survival (\%) of 30 flies (both gender) after 14 days of exposure of D. melanogaster to 7.5, 25, 50, 100, 200 and $500 \mu \mathrm{M} \mathrm{HgCl}_{2}$. Data are presented as mean \pm SEM of three independent biological replicates carried out in duplicates. Survival analysis was carried out in three independent experiments. $500 \mu \mathrm{M}$ was selected for further study based on the highest lethality at 7 days. 


\subsection{Effects of ackee leaves and arils on oxidative stress-antioxidant biomarkers.}

The effect of different concentrations of AL and AS on oxidative stress - antioxidant biomarkers are depicted in Figure 2. The result showed that AL and AS at concentrations studied $(0.1,0.2$, and $0.4 \mathrm{mg} / \mathrm{g}$ diet $)$, respectively reduced the level of nitric oxide and hydrogen peroxide and caused an increase in total thiol level, catalase, and GST activities when compared with the control.

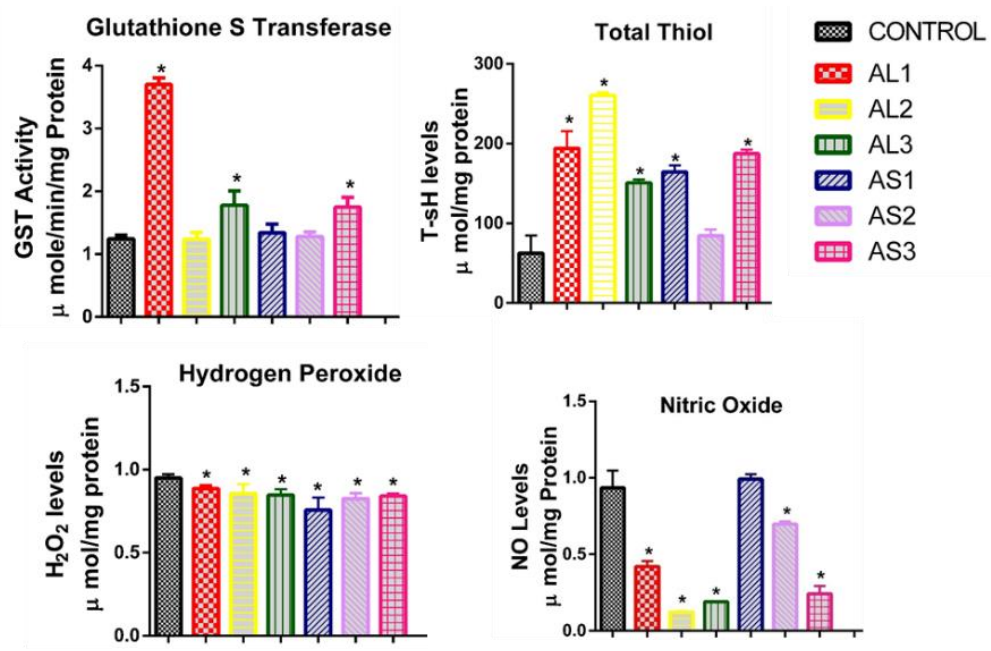

Figure 2. Effects of Blighia sapida leaves and arils on antioxidant-oxidative stress biomarkers in Drosophila melanogaster. Statistical analysis was performed using a one-way analysis of variance (ANOVA) followed by Tukey's post hoc test. Values are expressed as mean \pm SEM $(n=5)$. Significant differences from the control are indicated by * $(\mathrm{p}<0.05)$.

3.4. Effects of ackee leaves and arils on negative geotaxis, the emergence of offspring, and acetylcholinesterase activity.

The effect of different concentrations of AL and AS on negative geotaxis, emergence, and acetylcholinesterase activities is depicted in Figure 3. The result showed that the ackee leaves and arils extracts did not impair negative geotaxis as it was significantly $(p<0.05)$ improved, so also were the emergence of offspring and acetylcholinesterase activity increased when compared with control.
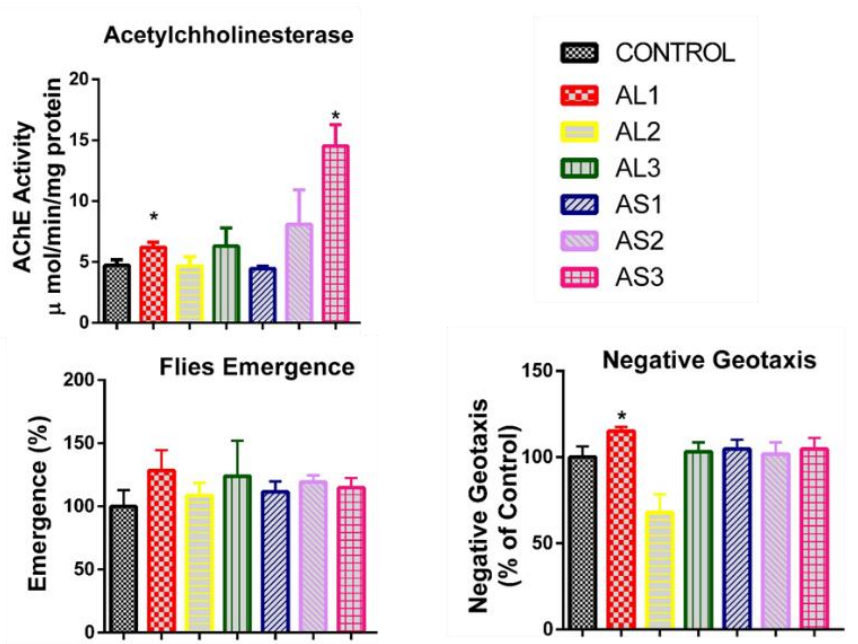

Figure 3. Effects of Blighia sapida leaves and arils on acetylcholinesterase activity, negative geotaxis, and flies emergence Drosophila melanogaster. Statistical analysis was performed using a one-way analysis of variance

(ANOVA) followed by Tukey's post hoc test. Values are expressed as mean \pm SEM $(n=5)$. Significant differences from the control are indicated by * $(\mathrm{p}<0.05)$. 


\subsection{Effects of mercuric-chloride on oxidative stress-antioxidant biomarkers.}

The effect of different concentrations of $\mathrm{HgCl}_{2}$ on oxidative stress - antioxidant biomarkers are depicted in Figure 4. The result showed that $\mathrm{HgCl}_{2}$ at all concentrations studied caused an increase in the level of nitric oxide and hydrogen peroxide while reduced total thiol level, catalase and GST activities when compared with the control $(p<0.05)$.
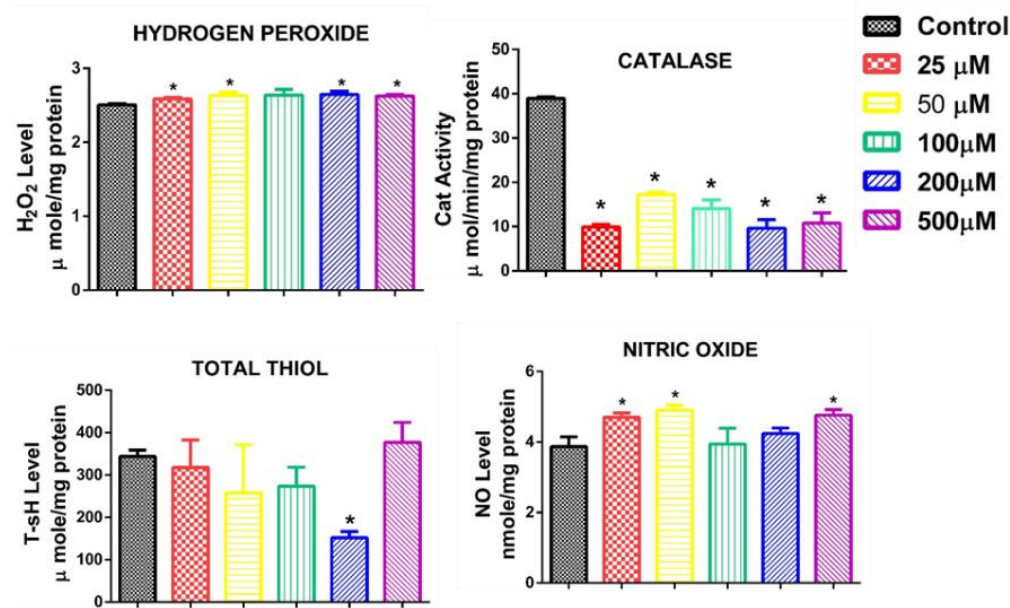

Figure 4. Effects of $\mathrm{HgCl}_{2}$ on antioxidant-oxidative stress markers in Drosophila melanogaster. Statistical analysis was performed using a one-way analysis of variance (ANOVA) followed by Tukey's post hoc test. Values are expressed as mean \pm SEM $(n=5)$. Significant differences from the control are indicated by ${ }^{*}(\mathrm{p}<$ $0.05)$.

3.6. Effects of B. sapida on mercuric chloride-induced oxidative stress and antioxidant imbalance.

The result showed that AL $(0.2 \mathrm{mg} / \mathrm{g})$ and AS $(0.4 \mathrm{mg} / \mathrm{g})$ were the most potent doses. Hence they were used to investigate the ameliorative effect on $\mathrm{HgCl}_{2}$. Figure 5 shows the effect of ackee extracts on $\mathrm{HgCl}_{2}$-induced oxidative stress and antioxidant imbalance. The results showed that ackee leaves and arils extracts reversed the elevated $\mathrm{H}_{2} \mathrm{O}_{2}$ and nitric oxide levels significantly $(p<0.05)$, which was caused by $\mathrm{HgCl}_{2}$ and also and the improved the total thiol levels, catalase and GST activities significantly ( $p<0.05$ ), which were previously reduced by $\mathrm{HgCl}_{2}$ when compared with control.
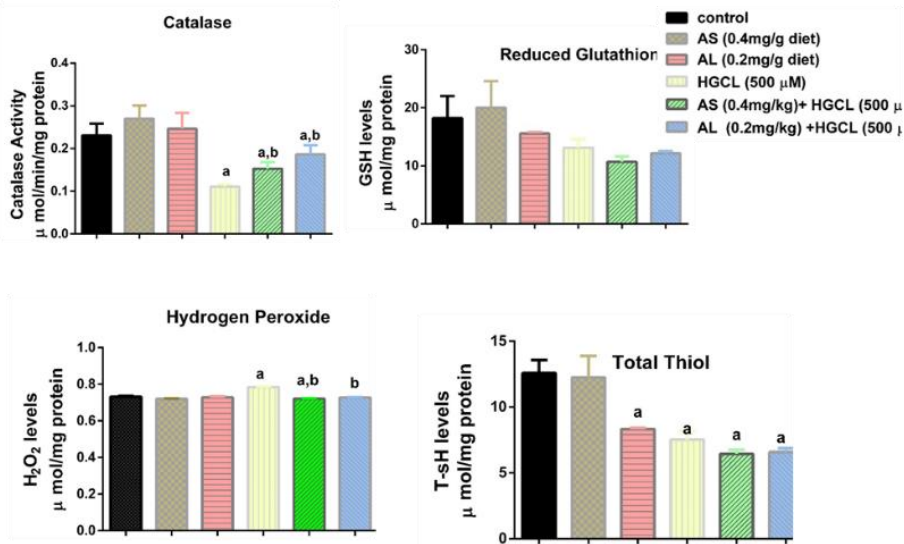

Figure 5. Effects of Blighia sapida leaves and arils on $\mathrm{HgCl}_{2}$-induced antioxidant-oxidative stress markers in Drosophila melanogaster. Statistical analysis was performed using a one-way analysis of variance (ANOVA) followed by Tukey's post hoc test. Values are expressed as mean \pm SEM $(n=5)$. Significant differences from the control are indicated by ${ }^{\mathrm{a}}(\mathrm{p}<0.05)$. Significant differences from $\mathrm{HgCl}_{2}$ are indicated by ${ }^{\mathrm{b}}(\mathrm{p}<0.05)$. 
3.7. Effects of B. sapida on mercuric chloride-induced inhibition of acetylcholinesterase activity.

The effect of ackee extracts on $\mathrm{HgCl}_{2}$-induced inhibition of acetylcholinesterase (AChE) activity is depicted in Figure 6. The result showed that AL and AS significantly restored $\mathrm{HgCl}_{2}$-induced inhibition of $\mathrm{AChE}$ activity when compared with control $(p<0.05)$.
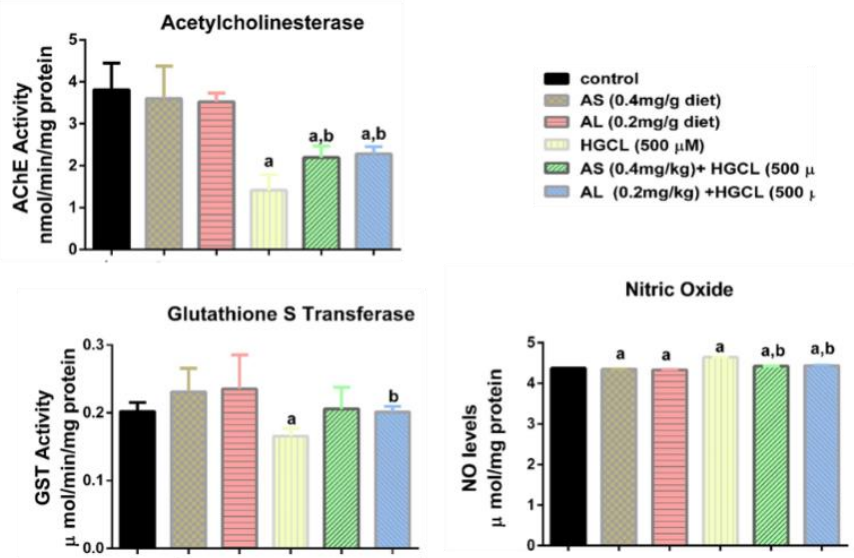

Figure 6. Effects of Blighia sapida leaves and arils in reversing the $\mathrm{HgCl}_{2}$ - induced inhibition of acetylcholinesterase and GST activities, and elevation of nitric oxide levels in Drosophila melanogaster. Statistical analysis was performed using a one-way analysis of variance (ANOVA) followed by Tukey's post hoc test. Values are expressed as mean $\pm \operatorname{SEM}(n=5)$. Significant differences from the control are indicated by ${ }^{\mathrm{a}}(\mathrm{p}<0.05)$. Significant differences from $\mathrm{HgCl}_{2}$ are indicated by ${ }^{\mathrm{b}}(\mathrm{p}<0.05)$.

\subsection{Discussion.}

The phytochemical analyzes of ackee leaves and arils extracts showed the presence of saponins, tannins, alkaloids, total phenol, terpenoids, and flavonoids but more abundant in the leaves than arils. The presence of these phytochemicals, e.g., flavonoids, have been reported to exert antioxidant [32], responsible for the reduction of oxidative stress markers, e.g., nitric oxide, hydrogen peroxide levels in treated flies and increase the activities of AChE and GST in D. melanogaster. Plants phytochemicals that can slow down the process of aging while extending lifespan is considered of great importance. Our results showed that AL and AS extracts extended the lifespan of D. melanogaster. This is in line with studies that showed that consumption of diet fortified with supplement rich in antioxidant property contributes to the longevity of organisms [33].

Exposures to environmental toxicants have been reported to cause oxidative stress [34]. In this study, mercuric chloride was used to investigate whether its exposure can induce oxidative stress in D. melanogaster. The results demonstrated that 14 days of exposure of mercuric chloride at concentrations $25,50,100,200$, and $500 \mu \mathrm{M}$ in flies decreased survival rate and impaired antioxidant defense system. It was observed that the independent administration of $\mathrm{HgCl}_{2}$ caused an increase in hydrogen peroxide and nitric oxide levels. This observation is consistent with a previous study by Stacchiotti et al. [35]. Also, $\mathrm{HgCl}_{2}$ caused a reduction in the activities of CAT, GST, and level of glutathione and total thiol while inhibiting the activity of AChE. This imbalance caused by ROS can be restored through the use of extracellular antioxidants which can boost the antioxidant defense of the body system [36]. Independent administration of ackee leaves and arils reduced the production of these reactive oxygen and nitrogen species while upregulating the activities of antioxidant enzymes and 
AChE. Ackee leaves and arils also improved climbing assay and rate of emergence of offspring. This depicts its antioxidative abilities.

Study on the effect of mercury as $\mathrm{HgCl}$ and $\mathrm{HgCl}_{2}$ on the antioxidant enzyme levels and its toxicity in an insect model which comprised of adult females of the common housefly (Musca domestica), and fourth-instar larvae of the cabbage looper moth (Trichoplusia ni), has shown that at approximately $0.005 \%$ for both insects (w/v for M. domestica and w/w for T. ni), induced the activity of SOD and CAT while activities of GST, GSTPX and GR were significantly altered [13]. An increase in GST activity after was observed on three days of exposure of D. melanogaster to $\mathrm{MeHg}^{+}$[18].

$\mathrm{AL}$ and $\mathrm{AS}$ were able to reverse the deleterious effect of $\mathrm{HgCl}_{2}$ significantly and increases the CAT activity, thus indicating its free radical scavenging potentials. GST serves as a sensor for oxidative stress in response to environmental pollutants, including metals, and AChE activity is used to assess the neurotoxic stress induced by contaminants [37]. Glutathione-S-transferase (GST) belongs to the phase II family of detoxifying enzymes that catalyze the conjugation of GSH to the electrophilic centers of exogenous and endogenous electrophiles [17]. Thus, the observed $\mathrm{HgCl}_{2}$ cause inhibition of GST activity implies that the response of the flies to combat oxidative stress was compromised. However, Ackee leaves and arils were able to reverse the inhibitory effect of mercuric chloride, indicating their antioxidative potentials. Thiols (-SH) are compounds with a carbon-bound sulfhydryl group, which are important antioxidant agents in the organism and defend against ROS [38]. Levels of protein -SH in the body is an indication of the body's antioxidant status [39]. Glutathione is the major intracellular protein thiol, and it is principally in the reduced form. The reduction of total thiol and GSH levels in D. melanogaster on exposure to $\mathrm{HgCl}_{2}$ indicate the inability of the flies to combat free radical damage. However, the result revealed that AL and AS ameliorated the mercuric chloride-induced depletion of total thiols and GSH confirming its antioxidant potential.

Acetylcholinesterase (AChE) is an enzyme that hydrolyzes acetylcholine, a neurotransmitter present in many synapses of the central nervous system (CNS) and plays an important role in coordination [40]. Our result shows inhibition of AChE activity on exposure to $\mathrm{HgCl}_{2}$ was reversed by supplementation of the diet with ackee leaves and arils extracts, with improved climbing performance in the flies. The inhibition of AChE will lead to high accumulation of acetylcholine at the synaptic junction, and this often results in various irregular muscle movements that could lead to convulsion, bronchial constriction, paralysis, and possibly death. This was evidently revealed in our results that showed improved flies' negative geotaxis when the diet was supplemented with the ackee extracts that reversed the inhibited AChE. Although an increase in acetylcholine concentration is very significant in brain cells as it improves communication between the nerve cells crucial for memory and cognitive functions. Figure 6 clearly showed that the ackee extracts (AL and AS) under the flies' normal physiological state reduces the activity of AChE, but not as drastic as the toxicant. Thus the ackee extracts possess the ability to improve the concentration of acetylcholine by slightly reducing the activity of $\mathrm{AChE}$ in a manner that will not trigger or degenerate into any other excessive physiological pattern or disorder as aforementioned. It could, therefore, be suggested that ackee leaves or arils, when consumed appropriately, could be a valuable therapeutic potential toward the management of dementia and possibly anti-aging as it will greatly improve mental alertness and function [41]. 
In this study, $\mathrm{HgCl}_{2}$ exposure increased nitric oxide (a highly diffusible and short lived free radical gas) level in D. melanogaster. The observation is similar to the report of Gado and Aldahmash [42] in which nitric oxide level was elevated in rats. Thus, the apparent suppression of mercuric chloride mediated accumulation of nitric oxide by ackee leaves, and arils could suggest its anti-inflammatory potential. Also, a study on the effect of D. melanogaster exposure to $\mathrm{Hg}^{2+}$ through diet has reported induction in mortality, altered locomotor performance as evaluated by negative geotaxis, and significant inhibition of GST, AChE, and SOD activities [43].

\section{Conclusions}

This study has demonstrated that Ackee leaves (AL) and Ackee arils (AS) extracts were able to ameliorate the effect of $\mathrm{Hg}^{2+}$ induced oxidative stress on CAT, AChE, GST, nitric oxide and hydrogen peroxide $\left(\mathrm{H}_{2} \mathrm{O}_{2}\right)$ production when compared to the control $(\mathrm{P}<0.05)$ in $D$. melanogaster. The concentration of mercuric chloride dose employed in this study $(500 \mu \mathrm{M})$ was far higher than the concentration range $(1.47 \mu \mathrm{M}-81 \mu \mathrm{M})$ proven to induce toxicity in human blood [44]. The significant degree of presence of phytochemicals in B. sapida extracts could be responsible for the observed pharmacological effects; therefore, it is suggested that the consumption of these ackee parts should be encouraged to provide therapeutic relieve perhaps not only to mercuric chloride toxicity but to any other known environmental toxicant. Furthermore, its administration towards other common illnesses could also be exploited.

It is also imperative that further works be carried out that will authenticate cytotoxicological safety of these extracts and the requisite amount that should be consumed that will not trigger or result in unwarranted illnesses, as these ackee arils most especially are consumed irrational whenever it is in season. Furthermore, in-depth structural characterization of these phytochemicals could be done as the information obtained may open a new platform for the design of synthetic therapeutic drugs, which may possess structural resemblance to these phytochemicals and thus provide similar biological antioxidant activities.

\section{Funding}

This research received no external funding.

\section{Acknowledgments}

Authors sincerely thank the Drug Metabolism and Molecular Toxicology Research Laboratories, Department of Biochemistry, Faculty of Basic Medical Sciences, College of Medicine, University of Ibadan, Oyo State, Nigeria for providing the Drosophila melanogaster used and bench space during the course of this work. Also, authors want to thank Federal University Oye Ekiti, Nigeria, and the University of Ibadan, Oyo State, Nigeria for unflinching research supports.

\section{Conflicts of Interest}

The authors declare no conflict of interest. 


\section{References}

1. Taek, M.T.; Prajogo, B.E.W.; Agil, M. Plants used in traditional medicine for treatment of malaria by Tetun ethnic people in West Timor Indonesia. Asian Pac J Trop Med 2018, 11, 630637, https://doi.org/10.4103/1995-7645.246339.

2. Samsonowicz, M.; Regulska, E.; Karpowicz, D.; Leśniewska, B. Antioxidant properties of coffee substitutes rich in polyphenols and minerals. Food Chem 2019, 278, 101-109, https://doi.org/10.1016/j.foodchem.2018.11.057.

3. Sinmisola, A.; Oluwasesan, B.M.; Chukwuemeka, A.P. Blighia sapida K.D. Koenig: A review on its phytochemistry, pharmacological and nutritional properties. J Ethnopharmacol 2019, 235, 446-459, https://doi.org/10.1016/j.jep.2019.01.017.

4. Lawal, R.T.; Oyeleke, G.O.; Ishola, A.D.; Akinsuroju, M.O. Determination of Physiochemical Properties and Lactic Acid Bacteria Presence in Ackee (Blighia sapida) Fruit. Int. J. Environ, Agri and Biotechnol 2018, 3, 1079-1082, http://dx.doi.org/10.22161/ijeab/3.3.47.

5. Kola, P.; Metowogo, K.; Kantati, Y.T.; Lawson-Evi, P.; Kpemissi, M.; El-Hallouty, S.M.; Mouzou, A.P.; Eklu-Gadegbeku, K.; Aklikokou, K.A. Ethnopharmacological Survey on Medicinal Plants Used by Traditional Healers in Central and Kara Regions of Togo for Antitumor and Chronic Wound Healing Effect. Evid Bas Complem and Alt Med 2020, 2020, 1-12, https://doi.org/10.1155/2020/6940132.

6. Grande-Tovar, C.D.; Delgado-Ospina, J.; Puerta, L.F.; Rodríguez, G.C.; Sacchetti, G.; Paparella, A.; Chaves-López, C. Bioactive micro-constituents of ackee arilli (Blighia sapida K.D. Koenig). An Acad Bras Cienc 2019, 91, 1-15, http://dx.doi.org/10.1590/0001-3765201920180140.

7. Ong, C.; Yung, L.Y.; Cai, Y.; Bay, B.H.; Baeg, G.H. Drosophila melanogaster as a model organism to study nanotoxicity. Nanotoxicol. 2015, 9, 396-403, https://doi.org/10.3109/17435390.2014.940405.

8. Allocca, M.; Zola, S.; Bellosta, P. The Fruit Fly, Drosophila melanogaster: Modeling of Human Diseases (Part II). In: Drosophila melanogaster-Model for Recent Advances in Genetics and Therapeutics. Intechopen 2018; pp. 131-156.

9. Nayfeh, A.; Kassim, T.; Addasi, N.; Alghoula, F.; Holewinski, C.; Depew, Z. A. Challenging Case of Acute Mercury Toxicity. Cas. Rep. In. Med 2018, 2018, 1-4, https://doi.org/10.1155/2018/1010678.

10. Vianna, A.D.S.; Matos, E.P.; Jesus, I.M.; Asmus, C.I.R.F.; Câmara, V.M. Human exposure to mercury and its hematological effects: a systematic review. Cad Saude Publica 2019, 35, https://doi.org/10.1590/0102311 X00091618.

11. Suhendrayatna, S.; Arahman, N.; Sipahutar, L.W.; Rinidar, R.; Elvitriana, E. Toxicity and Organ Distribution of Mercury in Freshwater Fi555sh (Oreochromis niloticus) after Exposure to Water Contaminated Mercury (HgII). Toxics 2019, 7, https://doi.org/10.3390/toxics7040058.

12. Mahapatra, C.T.; Bond, J.; Rand, D.M. Identification of Methylmercury Tolerance Gene Candidates in Drosophila. Toxicol Sci 2010, 116, 225-238, https://doi.org/10.1093/toxsci/kfq097.

13. Zaman, K.; MacGill, R.S.; Johnson, J.E.; Ahmad, S.; Pardini, R.S. An Insect Model for Assessing Mercury Toxicity: Effect of Mercury on Antioxidant Enzyme Activities of the Housefly (Musca domestica) and the Cabbage Looper Moth (Trichoplusia ni). Arch Environ Contam Toxicol 1994, 26, 114-118, https://doi.org/10.1007/BF00212802.

14. Norambuena, J.; Wang, Y.; Hanson, T.; Boyd, J.M.; Barkay, T. Low-Molecular-Weight Thiols and Thioredoxins Are Important Players in $\mathrm{Hg}(\mathrm{II})$ Resistance in Thermus thermophilus HB27. Appl Environ Microbiol. 2018, 84, e01931-17, https://doi.org/10.1128/AEM.01931-17.

15. Unsal, V. Natural Phytotherapeutic Antioxidants in the Treatment of Mercury Intoxication-A Review. $A d v$ Pharm Bull. 2018, 8, 365-376, https://doi.org/10.15171/apb.2018.043.

16. Liguori, I.; Russo, G.; Curcio, F.; Bulli, G.; Aran, L.; Della-Morte, D.; Gargiulo, G.; Testa, G.; Cacciatore, F.; Bonaduce, D.; Abete, P. Oxidative stress, aging, and diseases. Clin Interv Aging 2018, 13, 757-772, https://doi.org/10.2147/CIA.S158513.

17. Abolaji, A.O.; Kamdem, J.P.; Lugokenski, T.H.; Nascimento, T.K.; Waczuk, E.P.; Farombi, E.O.; Loreto, E.L.; Rocha, J.B. Involvement of Oxidative stress in 4 vinylcyclohexene-induced toxicity in Drosophila melanogaster. Free Radical Biol Med https://doi.org/10.1016/j.freeradbiomed.2014.03.014.

18. Piccoli, B.C.; Segatto, A.L.A.; Oliveira, C.S.; da Silva, F.D.; Aschner, M.; da Rocha, J.B.T. Simultaneous exposure to vinylcyclohexene and methylmercury in Drosophila melanogaster: biochemical and molecular analyses. BMC Pharmacol Toxicol 2019, 20, 83-99, https://doi.org/10.1186/s40360-019-0356-0.

19. Ojuederie, O.B.; Babalola, O.O. Microbial and Plant Assisted Bioremediation of heavy metal Polluted Environments: A Review. Int J Environ Res Pub Health 2017, 14, 1504-1529, https://doi.org/10.3390/ijerph14121504.

20. Skevas, T. Evaluating alternative policies to reduce pesticide groundwater pollution in Dutch arable farming. J Environ Plann and Manag 2020, 63, 733-750, https://doi.org/10.1080/09640568.2019.1606618.

21. Ezeonu, C.S.; Ejikeme, C.M. Qualitative and Quantitative Determination of Phytochemical Contents of Indigenous Nigerian Softwoods. N J. Sci. 2016, 2016, 1-9, https://doi.org/10.1155/2016/5601327. 
22. Ejikeme, C.M.; Ezeonu, C.S.; Eboatu, A.N. Determination of physical and phytochemical constituents of some tropical timbers indigenous to Niger Delta area of Nigeria. Euro Sci J. 2014, 10, 247-270.

23. Bohm, B.A.; Kocipai-Abyazan, R. Flavonoid and condensed tannins from the leaves of Vaccinum raticulation and Vaccinum calcyimium. Pac Sci 1994, 48, 458-463.

24. Khoddami, A.; Wilkes, M.A.; Roberts, T.H. Techniques for Analysis of Plant Phenolic Compounds. Mol 2013, 18, 2328-2375, https://doi.org/10.3390/molecules18022328.

25. Hassan, A.; Ullah, H.; Israr, M. The antioxidant activity and phytochemical analysis of medicinal plant $\begin{array}{llllll}\text { Veronica biloba. Lett Appl NanoBioScience, } & \mathbf{2 0 1 9}, & \text { 8(4), }\end{array}$ https://doi.org/10.33263/LIANBS84.732738.

26. Rahman, T. U.; Arshad, M.; Khan, S.; Zeb, M. A.; Liaqat, W. Phytochemical profile and biological investigation of Viburnum grandifloru. Lett Appl NanoBioScience, 2019, 8(4), 770-773 https://doi.org/10.33263/LIANBS84.770773.

27. Redmile-Gordon, A.; Armenise, E.; White, R.P.; Hirsch, P.R.; Goulding, K.W.T. A comparison of two colorimetric assays, based upon Lowry and Bradford techniques, to estimate total protein in soil extracts. Soil Biol Biochem 2013, 67, 166-173, https://doi.org/10.1016/j.soilbio.2013.08.017.

28. Ellman, G.L.; Courtney, K.D.; Andres, V.; Feather-Stone, R.M. A new and rapid colorimetric determination of acetylcholinesterase activity. Biochem Pharmacol 1961, 7, 88-95, https://doi.org/10.1016/0006-2952(61)90145-9.

29. Wolff, S.P. Ferrous ion Oxidation in the Presence of Ferric Ion Indicator Xylenol Orange for Measurement of Hydroperoxides. Methods Enzymol 1994, 233, 182-189, http://dx.doi.org/10.1016/S00766879(94)33021-2.

30. Jollow, D.J.; Mitchell, J.R.; Zampaglione, N.; Gillette, J.R.; Bromobenzene induced liver necrosis: protective role of glutathione and evidence for 3, 4 bromobenzene oxide as the hepatotoxic metabolite. Pharmacol 1974, 11, 151-169, http://dx.doi.org/10.1159/000136485.

31. Saraiva, M.A.; Ávila, E.R.; da Silva, G.F.; Macedo, G.E.; Rodrigues, N.R.; Vieira, P.B.; Nascimento, M.S.; Picoloto, R.S.; Martins, I.K.; de Carvalho, N.R.; Franco, J.L.; Posser, T. Exposure of Drosophila melanogaster to Mancozeb Induces Oxidative Damage and Modulates Nrf2 and HSP70/83. Oxidative Med Cellular Longevity 2018, 2018, 1-11, https://doi.org/10.1155/2018/5456928.

32. Ferreira, J.F.S.; Luthria, D.L.; Sasaki, T.; Heyerick, A. Flavonoids from Artemisia annua L. as antioxidant and their potential synergism with artermisinin against malaria and cancer. Mol 2010, 15, 3135-3170, https://doi.org/10.3390/molecules15053135.

33. Sadowska-Bartosz, I.; Bartosz, G. Effect of Antioxidants supplementation on Aging and Longevity. Biomed Res Int 2014, 2014, https://doi.org/10.1155/2014/404680.

34. Dugas, T.R. Unraveling mechanisms of toxicant-induced oxidative stress in cardiovascular disease. Curr Opin Toxicol 2018, 7, 1-8, https://doi.org/10.1016/j.cotox.2017.10.007.

35. Stacchiotti, A.; Ricci, F.; Rezzani, R.; Volti, G.L.; Borsani, E.; Lavazza, A.; Bianchi, R.; Rodell, L.F. Tubular Stress Proteins and Nitric Oxide Synthase Expression in Rat Kidney Exposed to Mercuric Chloride and Melatonin. J Histochem Cytochem. 2006, 54, 1149-1157, https://doi.org/10.1369/jhc.6A6932.2006.

36. Ihsan, A.U.; Khan, F.U.; Khongorzul, P.; Ahmad, K.A.; Naveed, M.; Yasmeen, S.; Yanfang, C.; Taleb, A.; Maiti, R.; Akhter, F.; Lia, X.; Cheng, Y.; Khan, H.U.; Alam, K.; Zhou, X. Role of oxidative stress in pathology of chronic prostatitis/chronic pelvic pain syndrome and male infertility and antioxidants function in ameliorating oxidative stress. Biomed Pharm 2018, 106, 714-723, https://doi.org/10.1016/j.biopha.2018.06.139.

37. Wu, F.; Huang, W.; Liu, Q.; Xu, X.; Zeng, J.; Cao, L.; Hu, J.; Xu, X.; Gao, Y.; Jia, S. Responses of Antioxidant Defense and Immune Gene Expression in Early Life Stages of Large Yellow Croaker (Pseudosciaena crocea) Under Methyl Mercury Exposure. Frontier Physiol 2018, 9, https://doi.org/10.3389/fphys.2018.01436.

38. Eren, M.A.; Koyuncu, I.; İncebıyık, H.; Karakaş, H.; Erel, O.; Sabuncu, T. The evaluation of thiol / disulphide homeostasis in diabetic nephropathy, Diabetes Res Clin Pract 2019, 148, 249-253, https://doi.org/10.1016/j.diabres.2019.01.022.

39. Circu, M.L.; Aw, T.Y. Reactive oxygen species, cellular redox systems and apoptosis. Free Radical Biol Med 2010, 48, 749-762, https://doi.org/10.1016/j.freeradbiomed.2009.12.022.

40. Cicchetti, F.; Drouin-Ouellet, J.; Gross, R.E. Environmental toxins and Parkinson's disease: What have we learned from pesticide-induced animal models? Trends Pharmacol Sci 2009, 30, 475-478, https://doi.org/10.1016/j.tips.2009.06.005.

41. Taylor, P.; Radić, Z. The cholinesterases: from genes to proteins. Annu Rev Pharmacol Toxicol 1994, 34 , 281-320, https://doi.org/10.1146/annurev.pa.34.040194.001433.

42. Gado, A.M.; Aldahmash, B.A. Antioxidant effect of Arabic gum against mercuric chloride-induced nephrotoxicity. Drug Des Develop Ther 2013, 7, 1245-1252, https://doi.org/10.2147/DDDT.S50928.

43. Paula, M.T.; Zemolin, A.P.; Vargas, A.P.; Golombieski, R.M.; Loreto, E.L.S.; Saidelles, A.P.; Picoloto, R.S.; Flores, E.M.M.; Pereira, A.B.; Rocha, J.B.T.; Merritt, T.J.S.; Franco, J.L.; Posser, T. Effects of Hg(II) Exposure on MAPK Phosphorylation and Antioxidant System in D. melanogaster. Environ Toxicol 2014, 6, 621-630, https://doi.org/10.1002/tox.21788. 
44. Brandao, R.; Lara, F.S.; Pagliosa, L.B.; Soares, F.A.; Rocha, J.B.T.; Nogueira, C.W.; Farina, M. Hemolytic Effects of Sodium Selenite and Mercuric Chloride in Human Blood. Drug Chem Toxicol 2005, 28, 397407, https://doi.org/10.1080/01480540500262763. 